\title{
MIODRAG A. VASILJEVICH AND FOLK MUSIC OF MACEDONIA
}

\begin{abstract}
In the versatile and comprehensive activity of Miodrag A. Vasiljevich, his initial research of the Macedonian musical-folkloristic heritage, continuously performed in the period 1931-1939, are of special importance. Such fieldwork on collecting and recording music-folkloristic material in various areas of the then Southern Serbia, combined by later material acquired from Macedonian students and radio singers in Belgrade, resulted in the collection titled Narodne melodije koje se pevaju u Makedoniji - Jugoslovenski muzichki folklor II [Folk Melodies Sung in Macedonia - Yugoslav Musical Folklore II], which was published in 1953. Based on existing records, as well as this accompanying study, this paper discusses the genre characteristics of songs, areas of their distribution, and especially models of metrorhythmic structuring and innovative ways of presenting them, with which Vasiljevich depicted the complexity of existing (metro)rhythmic patterns in Macedonian folk songs.
\end{abstract}

Keywords: ethnomusicological contribution of Miodrag A. Vasiljevich, folk music of Macedonia, Serbian ethnomusicology, musical metrics, hemiol measure.

This study is the result of the work on the project Music and Dance Tradition of Multiethnic and Multicultural Serbia (No. 177024), financed by the Ministry of Education, Science and Technological Development of the Republic of Serbia.

Miodrag A. Vasiljevich (1903-1963) was a sole exponent of Serbian regional ethnomusicology at the turn of the first and second half of the 20th century - a person who in Serbia, with his thoughts and deeds, connected two different epochs in the existence of our science, which were separated by the Second World War. He made his first collecting results in the interwar period, as the heir of his great predecessors who worked during the existence of comparative musicology - Stevan St. Mokranjac (1856 - 1914), Vladimir R. Djordjevich (1869 - 1938), Miloje Milojevich (1884 - 1946) and Kosta P. Manojlovich (1890-1949). He realized the peak of his creation in less than two decades of the post-war period, which coincides with the time of the birth and early maturation of ethnomusicology as the successor of the previously mentioned discipline. ${ }^{1}$ In that short period, he managed not only to significantly increase the corpus of collected materials and publish his most important works, but also to establish new research standards in Serbia and to set guidelines for his followers to act in the new era (Радиновић, 2016, 171).

Vasiljevich's pioneering achievements in the post-war period were numerous, diverse and so important for the Serbian environment that some authors rightly proclaimed him "the founder of modern Serbian ethnomusicology" (Лубен, 1993,

${ }^{1}$ Contrary to the often held view, ethnomusicology was not only a new name for comparative musicology, but it was an essentially new and independent scientific discipline, which adopted many elements from comparative and historical musicology, as well as from anthropology, linguistics and musical folklore (Cooley, 2005, 177). 
123), or even a person who should be considered the first Serbian ethnomusicologist in the full sense of the word (Марковић, 1993, 128-130; 1994, 22-23). For, he was the first person to opt for ethnomusicology as his basic profession, while his predecessors, by their primary vocation, remained committed to compositional creation or music pedagogy for the rest of their lives. In his scientific work, although not particularly fruitful, he was the first in our environment to dare to make extensive theoretical syntheses. He was the first to use the Finnish method in transcription and analysis (since 1950), and a magnetophone in field work (since 1951), ${ }^{2}$ practically as soon as this device entered commercial application in the world. He played a crucial role in starting the Department of Musical Folklore (1961) at the Belgrade Music Academy (today's Faculty of Music), as well as in founding several important folkloristic associations and events. ${ }^{3}$

Despite all that has been said, Vasiljevich is primarily mentioned as the most prolific melographer in the entire history of Serbian ethnomusicology so far. His great melographic results stemmed from the fact that he conducted his initial attempts during his childhood, practiced melography at a young age, and then maintained his full commitment to the field continuously and intensively for more than three decades, from 1931 to the end of his life. He made a visible contribution of this kind not only in Serbia, but also in other territories of the former common Yugoslav state. His melographic opus published so far, available to the public in dozen collections, consists of 3198 different recordings of primarily vocal melodies (not counting repeated editions and a small number of examples that have been published several times in various places) (Радиновић, 2016, 172). Of that, 422 records (with variants) originate from the territory of today's Republic of Northern Macedonia (Васиљевић, 1953), and as many as 1097 from Montenegro and from two enclaves of the Montenegrin population in Serbia and Croatia (cf. Васиљевић, 1953a; 1965; 1967; Radinovich, 2017; 2019). So, Vasiljevich accomplished almost half of his melographic results outside of Serbia. This fact clearly testifies to the width of his interests, as well as to his ambitious plans to prepare the basis for a comprehensive comparative study with his collections (Firfov, 1973, 25), which he did not manage to realize due to his untimely death.

The beautiful melos of Macedonia, which in the interwar period in the Kingdom of Yugoslavia was commonly considered Southern Serbia, ${ }^{4}$ magnetically

\footnotetext{
${ }^{2}$ Somewhat earlier in the same year, the magnetophone was first used for ethnomusicological purposes in a team field expedition at the places of the Bay of Kotor, organized by the Musicological Institute of SAS from 1951 to 1953. One of the members of the research team was Vasiljevich, acting as an external associate (Лазаревић, 1953; Лајић-Михајловић, 2010, 142; Лајић-Михајловић и Јовановић, 2014, 5).

${ }^{3}$ These are the Association of Folklorists of Serbia, the Union of Association of Folklorists of Yugoslavia and the Dragachevo Trumpet Festival.

${ }^{4}$ Here is how the famous Serbian ethnologist Jovan Erdeljanovich (1874-1944) explained the former framework of Southern Serbia: "The first South Slavic areas, ... are Northern and Southern Serbia. The northern part consists of the former Kingdom of Serbia before the World War, and the Southern Serbia includes Old Serbia and the northern part of Macedonia. Old Serbia consists of the entire former Novi Pazar Sandzak, the entire Kosovo-Metohija Region, and the areas around Tetovo, Skopje, Kratovo and Kochani, and the rest of Southern
} 
had attracted all Serbian music folklorists from the first half of the 20th century, including Vasiljevich, who in the early part of his working life belonged to that older research paradigm and brought it a worthy ending. However, it should be noted that an important part of the motivation of all these collectors from the mentioned era stemmed from the fact that, due to unfavorable circumstances that occurred after the Berlin Congress in 1878, the state policy of the Kingdom of Serbia and then of the Kingdom of Yugoslavia, found an important foothold in the strengthening of its southern territories (Jezernik, 2007, 211-218). From this, it can be understood why, in principle and in terms of cultural policy, there was a great insistence on collecting, researching and affirming the heritage of the "Serbian south".

The crucial moment in Vasiljevich's orientation towards this area happened between 1923 and 1926, when, after a break caused by the First World War, he attended the 6th and 7th grade of high school in the Macedonian city of Veles. During 1925 and 1926, he befriended Zhivko Firfov (1906 - 1984), a future famous Macedonian ethnomusicologist, with whom he occasionally collaborated in a string trio, playing the viola, and who introduced him to some of the then numerous and widely known folk musicians, singers and dancers (Васиљевић, 1973, 6; Фирфов, 1973, 20-21). The strength of the impression that the Macedonian melos made on Vasiljevich in that period is best evidenced by the fact that he requested the Ministry of Education the employment in Macedonia and managed to get it, immediately after graduating from the teaching-theoretical department and composition department in 1929/30 at the Music School in Belgrade (today's Music School "Mokranjac"). As early as January 1931, he was appointed as a temporary teacher of skills at the Women's Gymnasium in Skopje. He remained in that position, and then in the Men's Gymnasium, until 1937, when he returned to Belgrade at the invitation of Kosta P. Manojlovich, to join the teaching staff at the High School of Music and at the newly founded Music Academy (Васиљевић, 1973, 8, 11).

During the years spent in Macedonia, Vasiljevich showed great commitment not only to his pedagogical profession, but also to other forms of building musical culture in that part of the former Yugoslav state. In addition to fulfilling his regular teaching obligations and starting to create his original functional method of score singing on folk melodies, he acted as a choirmaster in an amateur society, played the viola in the Serbian String Quartet and in an orchestra composed of students, their professors and citizens. He was also dedicated (as an initiator and member of the organizing committee) to the founding of the first music school in Skopje, which began operating during the 1934/35 school year. Apart from all the above, during every school holiday, since 1931, he used to collect folk melodies from various parts of Macedonia (Васиљевић, 1973, 9; Фирфов, 1973, 23), so the mentioned year can be considered the beginning of his official career in musical folkloristic, ${ }^{5}$ which has since become his greatest and lifelong professional preoccupation.

Serbia belongs to Macedonia (with the cities of Shtip, Veles, Prilep, Ohrid, Bitola and Strumica). We take Macedonia in the form it mostly had in the time of the Macedonian King Philip. The same, and more southern, part of Macedonia belonged to Greece; and the smallest part, in the northeast, was in Bulgaria" (Erdeljanovich, 1924, 330-331).

${ }^{5}$ However, for unknown reasons, this beginning is usually related to 1932 , which should definitely be corrected. 
Vasiljevich's first Macedonian singers were his students from Skopje. Also, they initially provided him with valuable assistance in recording lyrics and other accompanying data related to the songs, and were at the same time a bridge towards older and more competent informants, i.e towards their parents and relatives. From the very beginning, Vasiljevich showed great communicativeness and skillfulness in field work in this area, which was significantly contributed by the fact that, being a child of peasant teachers, the mentality of the common people was very close to him. At first, he recorded melodies in Skopje and Skopje Montenegro, and then in other parts of Macedonia. He realized his last fieldwork expeditions in 1938 and 1939, the first years after his employment in Belgrade (Васиљевић, 1953, XI).

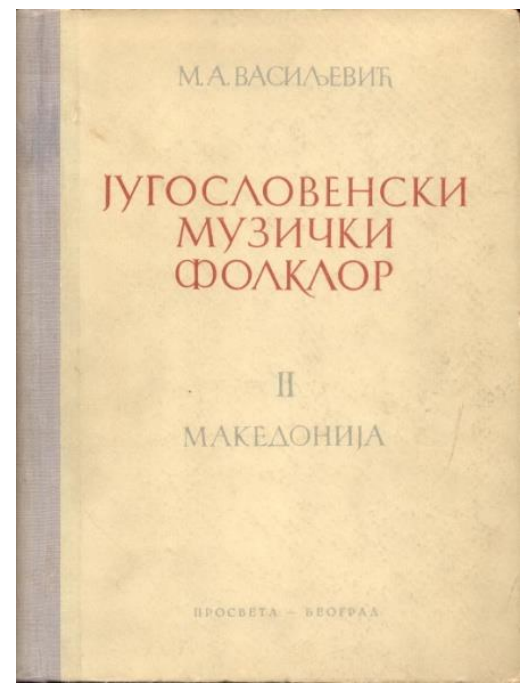

\section{Ilustration 1}

Vasiljevich managed to publish the results of his work in this area much later, in 1953, in a collection titled Narodne melodije koje se pevaju u Makedoniji [Folk Melodies Sung in Macedonia], the third book published during his lifetime, and the second and last from his ambitious series Yugoslav Musical Folklore (Васиљевић, 1953). According to the author's statement from the Foreword, that book, unfortunately, contains only a part of the material that he collected with great zeal for eight years, because the remaining material was destroyed in a fire at the train station during the bombing of Belgrade in April 1941 (which was the fate of some of his other manuscripts as well). The "basic material" consists of transcriptions from his last field trips, those relating to the "Mijak group" (Васиљевић, 1953, XI). Vasiljevich acquired some compensation for irretrievably the lost recordings with the examples from various parts of Macedonia that he transcribed in Belgrade from Macedonian students at the Music Academy, from Macedonian singers at Radio Belgrade (where he was formally engaged during several post-war years), as well as from several other informants (mostly from one journalist from Kichevo, with whom he collaborated in 1950) (1953, XI-XII). To this should be added a number of older examples (from 1931-1937) which, fortunately, were spared from the 
aforementioned fire, several of which he transcribed while listening to pre-war and post-war radio broadcasts, and some of his transcriptions originated from the Shtip festival held in 1947. Overall, the time span of the origin of the published transcripts is between 1931 and 1952. Although he published the Macedonian anthology two years after he started using a magnetophone in field work, Vasiljevich transcribed all his examples from Macedonia "by heart", both pre-war and post-war. Altogether, the time span of the origin of the published transcripts covers the period between 1931 and $1952 .^{6}$

The book presents mostly Macedonian urban melodies, nominally 400, and a couple of variants, which makes the total number to be 422 . Examples represent vocal heritage from many parts of Macedonia, but in different proportions - most of them are from Galichnik, then from Kichevo, Skopje, Berovo and Prilep, and less from Kavadarci, Radovishte, Tetovo, Krushevo, Veles, Bitola, Strumitza, Ohrid, Kratovo, Debar, Gevgelija, Kumanovo and Struga. The vast majority of this material comes from the area inhabited by Mijaks, the population of western Macedonia from the mountainous sides in the Radika river basin, as well as from the area where Brsjaks live, inhabitants of the central and southwestern part of the country, from the Bitola-Prilep valley.

Although Vasiljevich did not emphasize it anywhere, it is reasonable to assume that he consciously paid special attention to these two neighboring Slavic ethnic groups (partially Islamized, especially when it comes to the Mijaks), which history remembers from the time of the Slavic settlement. Endogamy and the warrior spirit have conditioned that they have preserved their specific anthropological characteristics, uniqueness and sharp features of isolation and separation to this day. The author was probably also motivated by the fact that many traces of Serbian origin and pre-Christian heritage are recognized in the toponymy of their habitats, in their oral tradition and ritual life (Цвијић, 1987, 449-457; Smiljanich, 1924; Smiljanich-Bradina, 1930; 1931).

No special attention was paid to the genre affiliation of the songs, and it was expressed only through notes to the lyrics and through the register "Texts by types", which shows that the criterion of genre classification was of secondary importance and inconsistent, a mixture of song function and content: love songs (162), pechalba songs $^{7}$ (18), humorous love songs (22), local and common love songs (5), family songs (2), wedding songs and dances (18), wedding humorous songs (4), wedding toasts (1), dances with singing (49), toasts (1), children's and humorous songs (3), other humorous songs (3), patriotic songs (15), rebel songs (4), komit songs ${ }^{8}$ (30), partisan songs (1), kolede songs ${ }^{9}$ (3), seasonal songs (18), ballads (2) (Васиљевић, 1953, 170). Except for one two-part example from Tetovo (No. 251), all the songs

${ }^{6}$ In the same way, he collected materials from Kosovo and Metohija, Sandzak and central Serbia (Васиљевић, 1973, 15). Before the Second World War, no one in Serbia used a phonograph for ethnomusicological purposes except Kosta P. Manojlovich (and before him, to a lesser extent, Borivoje Drobnjakovich).

${ }^{7}$ Songs about going to work abroad.

${ }^{8}$ Macedonian revolutionary songs from the end of the 19th and the beginning of the 20th century.

${ }^{9}$ Winter solstice songs. 
are unison, and, as can be seen from the previous census, mostly of general purpose and love content. The solitary two-part song is one of the few not only in Vasiljevich's overall melographic opus, but also in the legacy of all Serbian ethnomusicologists in general, obviously due to the difficulty of direct field transcription of such examples, unsupported by sound recordings:
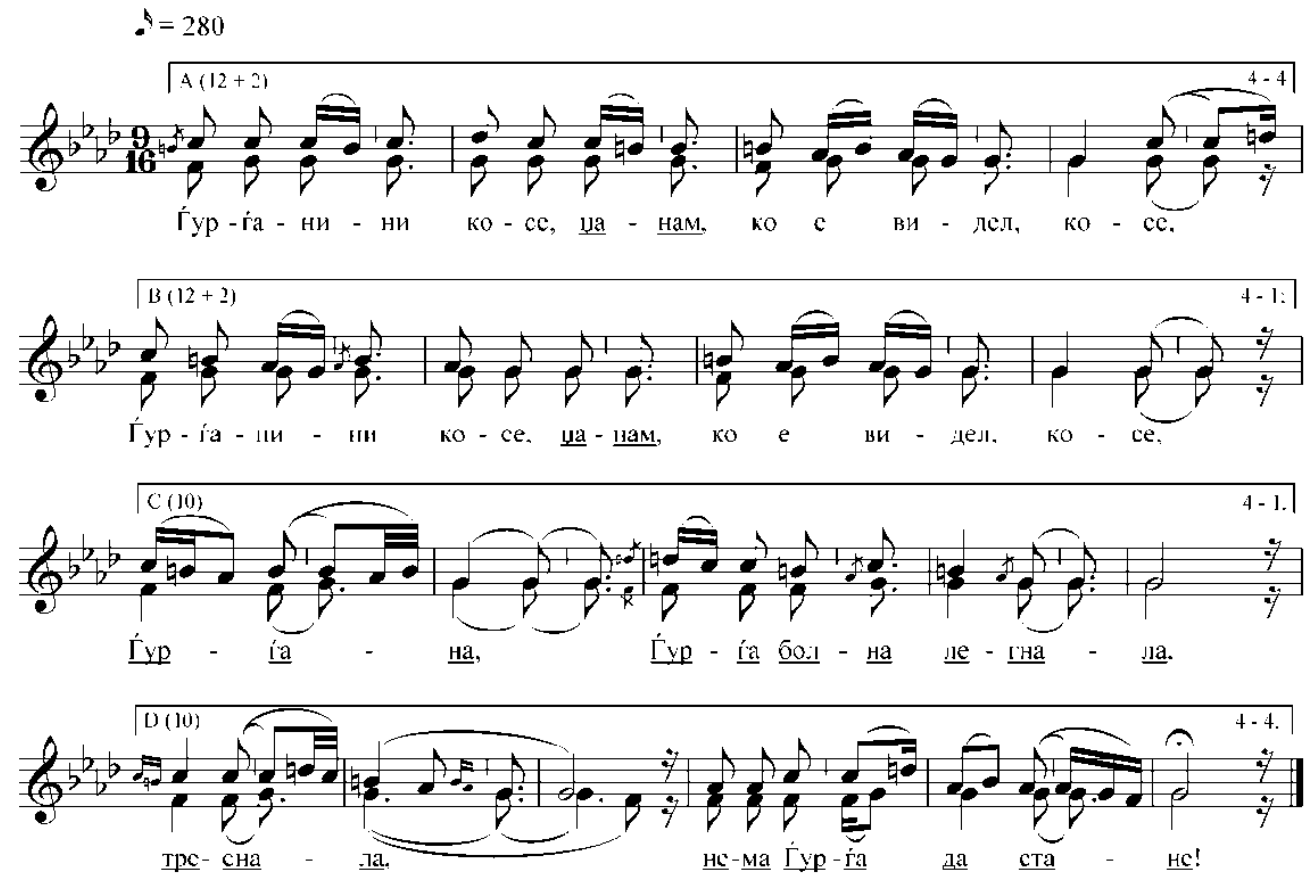

Ex. 2

Examples from this book contain formal analyzes according to the Finnish method, shown in Vasiljevich's modification and characteristically graphically presented: rectangular stylized long arcs above the note system denote separate melodic sections, within which letter and number symbols inscribed on the left describe the formal units of melopoetic form, while the numbers on the right refer to the pitch of its initial and final tone. ${ }^{10}$

As he did in the first collection from the series Yugoslav Musical Folklore, dedicated to the vocal heritage of Kosovo and Metohija (Васиљевић, 1950), the author in the study at the beginning of the book, entitled "Trochee ${ }^{11}$ metric forms in the musical folklore of Yugoslavia" (Васиљевић, 1953, XVII -LXIV), dealt with that parameter of the musical structure of the represented examples which he

${ }^{10}$ Such analyzes incorporated into transcriptions are otherwise a recognizable and unique feature of all Vasiljevich's anthologies published between 1953 and 1967 (Васиљевић, 1953; 1953a; 1960; 1965; Василевич, 1967). More details on this can be seen elsewhere (Радиновић, 2011, 61-67).

${ }^{11}$ Vasiljevich understood the term trochee more broadly in relation to the meaning it has in quantitative and tonal versification, applying this term to both two-part and three-part meters in which the accent is positioned at the very beginning (cf. Васиљевић, 1953, XXI). 
considered dominant - therefore, in this case with musical metrics as the most impressive feature of Macedonian melos. He started from the constatation that the rhythmic component prevails in the folk music of Yugoslavia, and that the text, harmony, melismatics, form and tonal colorit are subordinated to that ancient feature. He believed that folk music metrics manifested its speech origin, due to the fact that the metrics of folk poetic speech prevailed in folklore melodies, which, furthermore, were very close to the expression of folk prose in their accentuated characteristics. And all mentioned is most evident and is best preserved in Macedonian folk music (1953, XVIII-XIX). He also believed that in the Macedonian vocal heritage, melodies have primacy over the content of the lyrics of folk songs, which is quite the opposite of the situation he found with the Dinaric population of Yugoslavia: "The simplicity of the melody in this way of expression tends to express the text with as few musical means as possible. The goal of this type of creation is a text, and music is a means of expressing it. In Macedonia - although the text can often shine with its extraordinary beauty - in the relation of the melody to the text we have the opposite case: here the main purpose of creation is, - the melody. This collection speaks most eloquently about that." And again, Vasiljevich thought that even the melismatics of Macedonian melodies was also in the service of emphasizing the rhythmic component (1953, XIX).

The key point of the study is the division into simple and complex bars. The simple ones are called monopodias or meters (two-part and three-part), while the complex ones, which are created by combining the same or different meters, are called polypodias. Joints of the same meters produce equally composed bars, while mixed or hemiol bars result from the association of different ones - which are, as it is known, characteristic for the Macedonian heritage.

Vasiljevich divided polypodias into seven species, starting from dipodias (double) to octopodias (eightfolds). He further classified the species into classes, and them into accent images. He described and commented on all these categories, from monopodias to octopodias, and illustrated them with musical examples and metrorhythmic patterns. In the end, he systematized them through a lucidly chosen mathematical model - within the pyramid scheme of so-called Pascal's triangle (1953, LIV): 


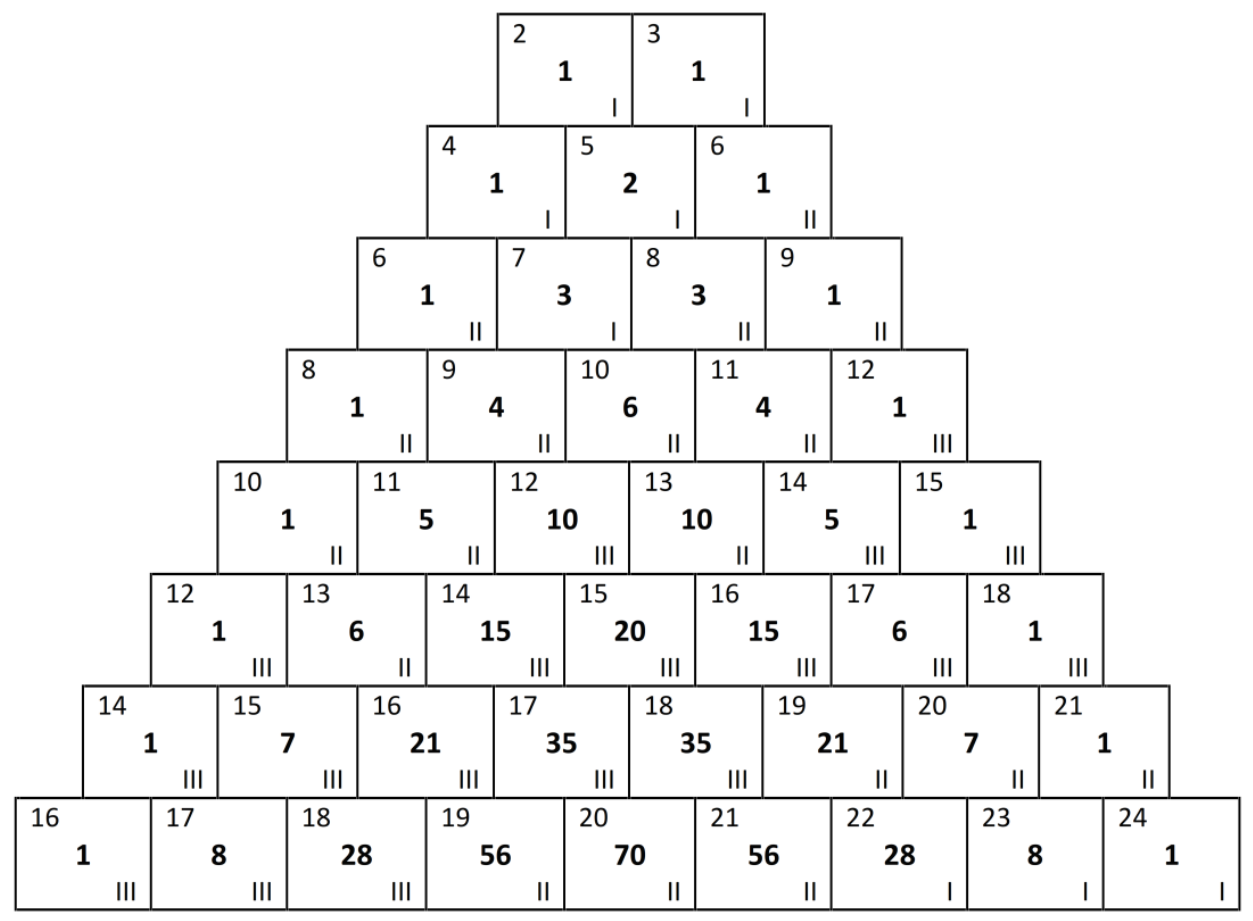

Ex. 3

Separate rows represent existing species: the row at the top of the pyramid shows monopodias, and all other polypodias, from dipodias to octopodias. The number in the upper left corner of each cell, i.e. class, refers to the number of chronos protoses in the bar, the number in the middle to the number of possible accent images, and the one in the lower right corner to the unambiguity, ambiguity or triple meaning of the indicated number of chronos protoses, in terms of its presence in the shown Pascal triangle. For example, the second cell in the third row, marked with the numbers 7, 3 and I, represents the bar with 7 chronos protoses, e.g. $7 / 8$, which is built by two two-part and one three-part meters. Depending on their arrangement within the bar, 3 accent images are possible. ${ }^{12}$ The Roman number I means that the bar with 7 chronos protoses is unambiguous, because it appears in only one place in Pascal's triangle:

${ }^{12}$ It is understood that the accent always falls on the first chronos protos in the meters. See previous note. 

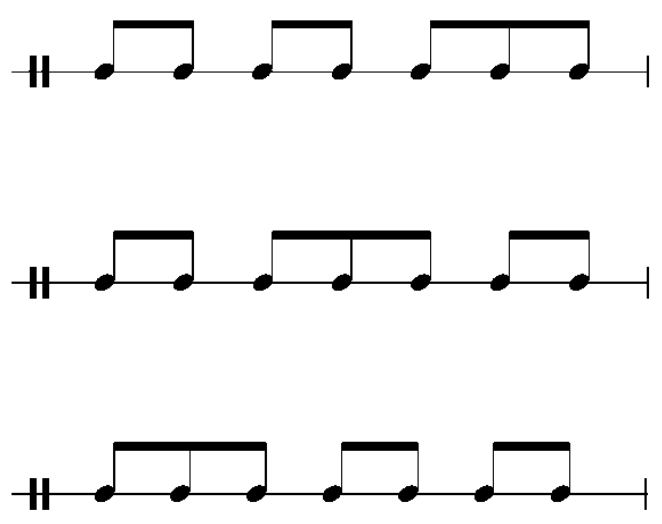

Ex. 4

The sloping edges of the pyramid refer to equally composed bars (of course, except for the top row, in which there are monopodias) - the left edge of the scheme represents the bars made of two-part meter, and the right edge represents the bars made of three-part meter (which is why they always have only one accent image). The remaining, inner cells, represent mixed bars, created by combining two-part and three-part meters in all possible combinations.

The entire systematization of examples in the collection also stems from the whole presented in this way. It should be borne in mind, however, that not all theoretical possibilities from the presented pyramid scheme appear in practice.

Vasiljevich's study ends with an appendix dedicated to his preliminary observations on the symmetry of metric forms. Unfortunately, this intriguing topic has not received a significant elaboration in Serbian ethnomusicology until today. Similarly, the entire study is the first and one of the few that explicitly deals with rhythm and musical metrics in the entire history of this science in Serbia, which gives it a special historical significance.

Vasiljevich's connection with the Macedonian folk songs is not exhausted, however, with the considered collection and the attached study, but also concerns his engagement in Radio Belgrade, as he himself hinted in the Preface. Namely, back in 1940, when there was a change in the management staff in this institution, Vasiljevich, at the request of the Government of the Kingdom of Yugoslavia, was invited by the retired Minister Janjich, then president of the radio station's board, to make a strategic draft of its activities in the area of folk music. He fulfilled that task very quickly and with quality, manifesting himself as an ardent patriot and protector of Serbian traditional culture, but anyway, at that time, his draft did not come to life. It was not established even in the first post-war years, from November 1944 to 1947, when Vasiljevich was engaged in Radio Belgrade by the communist authorities (Васиљевић, 1973, 13-14; Радујевић-Суса, 2006), who formally assigned him various prominent functions, among others even the function of the chief of the folklore department. His activities in that institution were diverse, and they partially continued after the dismissal he asked for in 1947. First of all, he prepared performances of radio singers for presentation of folk songs according to his transcriptions, among which were those from Macedonia, and he realized a series of 
10 music-folklore radio lectures with sound examples, derived from his field work and scientific knowledge. ${ }^{13}$ Unfortunately, apart from these basic facts, nothing more can be said about that for now. This is because the Music Archive of Radio Belgrade does not contain almost any data on Vasiljevich's long lasted engagement - neither his records on the basis of which he worked, nor files, nor recordings of the singers with whom he collaborated between 1944 and 1955, nor even their names. The same applies to the data on the mentioned series, as well as to the recordings of those broadcasts..$^{14}$ It is obvious that, in the period of communist censure, the management of Radio Belgrade wanted to take advantage of Vasiljevich's reputation and knowledge, but at the same time, due to his proven commitment to Serbian national interests, did not allow him to express himself professionally. In the end, that administration also systematically removed all traces of his activities (РадујевићCyca, 2006, 109-123). Fortunately, certain information about all this exists in Vasiljevich's manuscripts (Радујевић-Суса, 2006, 132). However, they are not yet available to the public, so final knowledge on the given issues can be expected from some future researchers. When it comes to Vasiljevich's cooperation with Macedonian radio singers, the data from the collection confirm them, but they are not very concise and are incomplete - they are reduced to the author's mention of that in the Preface, while the register of informants still does not provide any clearer information.

$$
* * *
$$

Therefore, based on the presented data, there is no doubt that Vasiljevich's initial research of musical-folklore material, conducted in the period from 1931 to 1939 on the territory of today's Republic of North Macedonia, established his greatest and lifelong preoccupation - professional engagement in musical folkloristics. The results of this research, as well as the latter conducted in Belgrade (through cooperation primarily with Macedonian students at the Music Academy and Macedonian singers at Radio Belgrade), became available to the general public in 1953, in the book we discussed in more detail here. This publication (with a total of 422 examples, including variants) covers mostly Macedonian urban melodies recorded in various parts, especially from the western area inhabited by Mijaci, as well as from the central and southwestern areas where the Brsjaci live. With monophonic recordings of vocal melodies of different genres (of predominantly general purpose and love themes), Vasiljevich added only one two-part example from Tetovo. Given the complexity of their two-voice factures, and due to the lack of sound recorders in the field, examples of two-part singing were also a real rarity in the work of other Serbian melographers of that time. This record in itself, attached here for illustration, indicates Vasiljevich's use of formal analysis according to the

${ }^{13}$ It is believed that this series was commissioned by composer Josip Kalchich (1912-?), who was the chief of the Music Program with the Ensembles of Radio Belgrade in the period from 1953 to 1963 (Радујевић-Суса, 2006, 122).

${ }^{14}$ It was planned that all broadcasts would be published in a separate issue of Radio Revija in 1959, but in the end that did not happen either (Радујевић-Суса, 2006, 123). 
Finnish method, which he, in a modified and simplified form, was the first to apply in Serbian ethnomusicology in 1950. In the study given at the beginning of the collection, Vasiljevich emphasizes the dominance of the melodic component in relation to the content of the text, and pays special attention to the metrorhythmic structuring of these melodies. He starts from the division into simple and complex bars, dwelling primarily on complex mixed or hemiol ones (specific for the heritage of Macedonian folklore). Further classification of bars into types, classes and accent images resulted in their systematization in the form of a pyramidal scheme of socalled Pascal's triangle. Specific and different metrorhythmic phenomena were also a key parameter in the classification of examples in the collection. Such an innovative methodological approach to the consideration of (metro)rhythmic features of melodies, together with observations on the symmetry of metric forms, deserves special attention in the history of ethnomusicology. Vasiljevich significantly promoted his field and scientific knowledge of Macedonian musical folklore through later broadcastings on Radio Belgrade, manifesting himself, in that way too, as a significant breakthrough in the field of ethnomusicological activities, in order to increase the visibility and importance of preserving musical elements of the national cultural significance.

\section{LITERATURE}

\section{CYRILIC}

ВАСИЛЕВИЧ, М. (Аксюк, С. В. [ур.]) (1967). Югославские народные песни из Санджака (записаны от народного певца Хамдии Шахинпашича). Москва: Музыка.

ВАСИљЕВИЋ, 3. М. (1973). „Живот и рад Миодрага А. Васиљевића“. Народно стваралаштво - folklor, год. ХІІ, св. 47-48, 1-19.

ВАСИЉЕВИЋ, М. А. (1950). Југословенски музички фолклор I - Народне мелодије које се певају на Космету. Београд: Просвета.

ВАСИЉЕВИЋ, М. А. (1953). Југословенски музички фолклор II Народне мелодије које се певају у Македонији. Београд: Просвета.

ВАСИЉЕВИЋ, М. А. (1953a). Народне мелодије из Санцака. САН, Посебна издања, књ. CCV, Музиколошки институт, књ. 5. Београд: Научна књига.

ВАСИљЕВИЋ, М. А. (ур. С. Ђурић-Клајн). (1965). Народне мелодије Црне Горе. Музиколошки институт, Посебна издања, књ. 12. Београд: Научно дело.

ЛАЗАРЕВИЋ, С. (1953). „Музички фолклор Боке Которске“. Из Споменика САН СІІІ - Зборник извештаја о истраживањима Боке Которске. Београд: [б. и.], 235-245.

ЛАЈИЋ-МИХАЈЛОВИЋ, Д. (2010). „Фоно збирка Музиколошког института САНУ“. Музикологија, бр. 10, 141-146.

ЛАЈИЋ-МИХАЈЛОВИЋ, Д. и Ј. Јовановић. (2014). „Историјат сакупљања теренских звучних записа традиционалне музике у Музиколошком институту САНУ“. У: Данка Лајић-Михајловић и др. (ур). Фоноархив 
Музиколошког института САНУ: историјски звучни записи у дигиталној ери. Београд: Музиколошки институт САНУ, 2-12.

ЛУБЕН, Х. (1993). „Миодраг А. Васиљевић - оснивач српске етномузикологије (поводом тридесетогодишњице смрти)“. Расковник, год. XIX, бр. 73-74, 117-123.

МАРКОВИЋ, М. (1993). „Како је настао први српски етномузиколог (прилог проучавању... српске етномузикологије)“. Расковник, год. ХІХ, бр. 73$74,124-131$.

МАРКОВИЋ, М. (1994). „Етномузикологија у Србији“. Нови Звук, бр 3 , 19-30.

РАДИНОВИЋ, С. (2011). Облик и реч (Закономерности мелопоетског обликовања српских народних песама као основа за методологију формалне анализе). Етномузиколошке студије - дисертације, св. 3. Београд: ФМУ.

РАДИНОВИЋ, С. (2016). „Васиљевићеви зборници народних мелодија: српско музичко благо“. Музикологија I (20), 171-198.

РАДУЈЕВИЋ-СУСА, Т. (2006). „Миодраг А. Васиљевић у Радио Београду у првој половини XX века“. У: Љубинковић, Н. и 3. М. Васиљевић (ур.). Миодраг А. Васиљевић - живот и дело (Зборник радова са округлог стола одржаног октобра 2003. године). Београд: Институт за књижевност и уметност, Удружење грађана „Миодраг А. Васиљевић“, 105-132.

ФИРФОВ, Ж. (1973). „Поводом десетогодишњице смрти професора Миодрага Васиљевића“. Народно стваралаштво - folklor, год. XII, св. 47-48, 20-27.

ЦВИЈИЋ, Ј. (ур. В. Чубриловић) (1987). Балканско полуострво. Јован Цвијић - Сабрана дела 2. Београд: САНУ, Књижевне новине, Завод за уџбенике и наставна средства.

\section{LATIN}

COOLEY, T. (2005). "Buduchnost etnomuzikoloshkog terenskog rada". IV medzunarodni simpozij „Muzika u drushtvu” (Sarajevo, 28-30. oktobar 2004). Sarajevo: Muzikoloshko drushtvo FBiH, Muzichka akademija u Sarajevu, 174-182.

ERDELJANOVICH, J. (1924). "Etnichki polozhaj Srba Stare Srbije i Makedonije medzu Juzhnim Slovenima“. Нова Европа, књ. Х, бр. 11, 327-335.

JEZERNIK, B. (2007). "IX Istinska komedija zabune". Divlja Evropa (Balkan u ochima putnika sa Zapada). Beograd: Biblioteka XX vek, Knjizhara Krug, 191218.

RADINOVICH, S. (2017). "On the Joined Endeavours by the Custodians of a Unique World of Beauty". In: M. A. Vasiljevich (ed. Drobni, I.). Zbornik narodnih pjesama (po pjevanju Hamdije Shahinpashicha). Podgorica: Muzichki centar Crne Gore, 27-38.

RADINOVICH, S. (2019). "Folk Songs of Montenegro in the Published Melographic Recordings of Miodrag A. Vasiljevich“. In: M. A. Vasiljevich. (eds. Mirkovich, Zh., I. Drobni and S. Radinovich). Narodne pjesme Crne Gore (u objavljenim melografskim zapisima). Podgorica: CANU, Muzichki centar Crne Gore, 19-31. 
SMILJANICH, T. (1924). Plemenske odlike Mijaka. Narodna Starina, br. 7 (3), 61-74. http://hrcak.srce.hr/search/?q=Plemenske+odlike+Mijaka [Accessed 13.01.2016].

SMILJANICH-BRADINA, T. (1930). Anciennes tribus serbes Les Mijaks, Les Brsjaks et leurs voisins dans la Serbie Méridionale. Skoplje: Knjizhara Jovana Dj. Popovicha.

SMILJANICH-BRADINA, T. (1931). "Brsjaci". Narodna Starina, br. 25 (10), 81-95. http://hrcak.srce.hr/search/?q=Brsjaci [Accessed 13.01.2016].

Сања Радиновиќ и Мирјана Закиќ

\section{МИОДРАГ А. ВАСИЛЕВИК์ И НАРОДНАТА МУЗИКА НА МАКЕДОНИЈА}

Резиме

Истражувањата на Миодраг А. Василевиќ за вокалниот музички фолклор на Македонија, кои се одвиваа од 1931 до 1939 година во разни краеви на тогашниот геополитички простор на Јужна Србија, беа мотивирани од специфичниот и од преубавиот мелос, втемелен на вистинското богатство на различните метроритмички обрасци. Од друга страна, вакви истражувачки потфати на подрачјето на „српскиот југ“, беа поттикнати од државно-политичката потреба, најпрво во Кралството Србија, а потоа во Кралството Југославија.

Од посебно значење е што токму овие теренски истражувања на Василевиќ, за музичко-фолклорниот материјал, ја насочија и ја предодредија неговата примарна професионална преокупација - интересот за музичката фолклористика. Ваквиот почетен импулс беше остварен благодарение на неговата осумгодишна практика во теренското истражување на музичкиот фолклор од различни македонски и српски области, втемелени врз основа на искази и на интерпретации на македонските студенти и на македонските радиски пејачи, кое, во 1953 година, резултираше со зборникот Народне мелодије које се певају у Македонији (Народни песни кои се пеат во Македонија) - Југословенски музички фолклор II, а кој содржи 422 записи на вокални мелодии.

Во студијата, која следи по овој зборник, Василевиќ посебно ја истакна важноста на мелодијата во однос на содржината на поетскиот текст. Тој посебно внимание му посвети на формалното обликување на мелодиите (според основниот принцип на т.н. „фински метод“), како и на метроритмичкото структурирање на напевот низ комплексната поделба на метричките видови и нивното претставување преку пирамидална шема, преку т.н. „Паскалов триаголник“, истовремено нагласувајќи ја особеноста на мешаните или хемиолни тактови, кои се карактеристични за македонскиот музички фолклор.

Василевиќ, своите теренски и научни сознанија за македонскиот музички фолклор, во значајна мера ги промовираше и по пат на серијалите емитувани на радио „Белград“, што сведочи за неговата посветеност за зачувување на традиционалното музичко наследство и за негово експонирање во домашните и во странските научни кругови. 